\title{
Diet segregation in American bison (Bison bison) of Yellowstone National Park (Wyoming, USA)
}

\author{
John L. Berini ${ }^{1 *}$ and Catherine Badgley ${ }^{2}$
}

\begin{abstract}
Background: Body size is a major factor in the nutritional ecology of ruminant mammals. Females, due to their smaller size and smaller rumen, have more rapid food-passage times than males and thereby require higher quality forage. Males are more efficient at converting high-fiber forage into usable energy and thus, are more concerned with quantity. American bison are sexually dimorphic and sexually segregate for the majority of their adult lives, and in Yellowstone National Park, they occur in two distinct subpopulations within the Northern and Central ranges. We used fecal nitrogen and stable isotopes of carbon and nitrogen from American bison to investigate sex-specific differences in diet composition, diet quality, and dietary breadth between the mating season and a time period spanning multiple years, and compared diet indicators for these different time periods between the Northern and Central ranges.

Results: During mating season, diet composition of male and female American bison differed significantly; females had higher quality diets, and males had greater dietary breadth. Over the multi-year period, females had higher quality diets and males, greater dietary breadth. Diet segregation for bison in the Central Range was more pronounced during the mating season than for the multi-year period and females had higher quality diets than males. Finally, diet segregation in the Northern Range was more pronounced during the multi-year period than during the mating season, and males had greater dietary breadth.

Conclusions: Female bison in Yellowstone National Park have higher quality diets than males, whereas males ingest a greater diversity of plants or plants parts, and bison from different ranges exhibited more pronounced diet segregation during different times. Collectively, our results suggest that diet segregation in bison of Yellowstone National Park is associated with sex-specific differences in nutritional demands. Altogether, our results highlight the importance of accounting for spatial and temporal heterogeneity when conducting dietary studies on wild ungulates.
\end{abstract}

\section{Background}

Body size is a major factor in the nutritional ecology of ruminant mammals, as mass-specific energy demands generally decrease with increasing body mass [1]. On average, the ability of ungulates to convert high-fiber, low-quality forage into usable energy increases with body size, a trend known as the Jarman-Bell principle $[2,3]$. Although the Jarman-Bell principle was first used

\footnotetext{
*Correspondence: beri0015@umn.edu

${ }^{1}$ Department of Fisheries, Wildlife, and Conservation Biology, University of Minnesota, 135 B Skok Hall, 2003 Upper Buford Circle, St. Paul, MN 55108-1052, USA

Full list of author information is available at the end of the article
}

to explain dietary differences among African ruminants of varying sizes $[2,3]$, evidence suggests that the principles upon which the Jarman-Bell principle is founded hold true for dietary differences within species as well, and therefore, may help explain sexual segregation in sexually dimorphic ruminants [4]. Applying the Jarman-Bell principle to size-dimorphic ruminants suggests that smaller individuals should be more selective feeders and have higher quality diets than larger individuals $[2-4]$. In sexual segregation theory, the forageselection hypothesis suggests that females, due to their smaller size and smaller rumen, have more rapid foodpassage times than males and thereby require higher quality forage in order to maintain body weight. Males, 
with larger size and longer food-retention times, are more efficient at converting high-fiber forage into usable energy and thus, are more concerned with quantity [5-7]. Although numerous hypotheses have been invoked to explain sexual segregation in ruminants (for a review see [8]), this phenomenon is best characterized as the differential use of space, habitat, or food by males and females.

Sexual dimorphism and segregation in large mammals are typically associated with sex-specific differences in energetic requirements and digestion [9]. For example, the activity budget hypothesis assumes that females are less efficient at digesting forage than males, and therefore spend more time foraging, whereas males spend more time ruminating [10]. While the forage-selection hypothesis also assumes that females are less efficient at digesting forage, this hypothesis predicts group formation based on dietary preferences as opposed to activity budget. American bison (Bison bison) are highly sizedimorphic, with the average male $(800 \mathrm{~kg})$ weighing roughly $350 \mathrm{~kg}$ more than the average female $(450 \mathrm{~kg}$; [11]). Reproductively active females have higher energy demands than males due to gestation and lactation, with energetic requirements peaking during early to midsummer $[12,13]$. The energetic demands of males also peak during early to mid-summer, when mature individuals are replenishing energy stores in preparation for the rut, which occurs during late summer [12, 14]. During the rut, male and female bison spend approximately 1 month in large mating groups, with males tending to potential mates in an effort to maximize breeding potential [15]. Throughout the rest of the year, males and females remain segregated. Collectively, the anatomical, behavioral, and physiological differences between male and female American bison make them an ideal species for studies of diet segregation. Previous studies of sexual segregation in American bison provide evidence for both the forage-selection hypothesis and the predation-risk hypothesis. The latter assumes that females and their calves are more vulnerable to predation than males and therefore select habitats that provide increased safety over increased forage quality $[5,16]$.

In Yellowstone National Park (YNP), the bison population consists of two geographically and ecologically distinct subpopulations. In the Northern and Central ranges of YNP (Fig. 1), bison populations differ in fetal growth rates [17], median calving dates [17], and tooth-wear patterns [18]. Differences in mtDNA haplotype frequencies between ranges provide evidence for assortative breeding [19], and since their reintroduction in 1995, wolf predation rates on bison have been higher in the Central Range than in the Northern Range [20, 21]. Additionally, higher

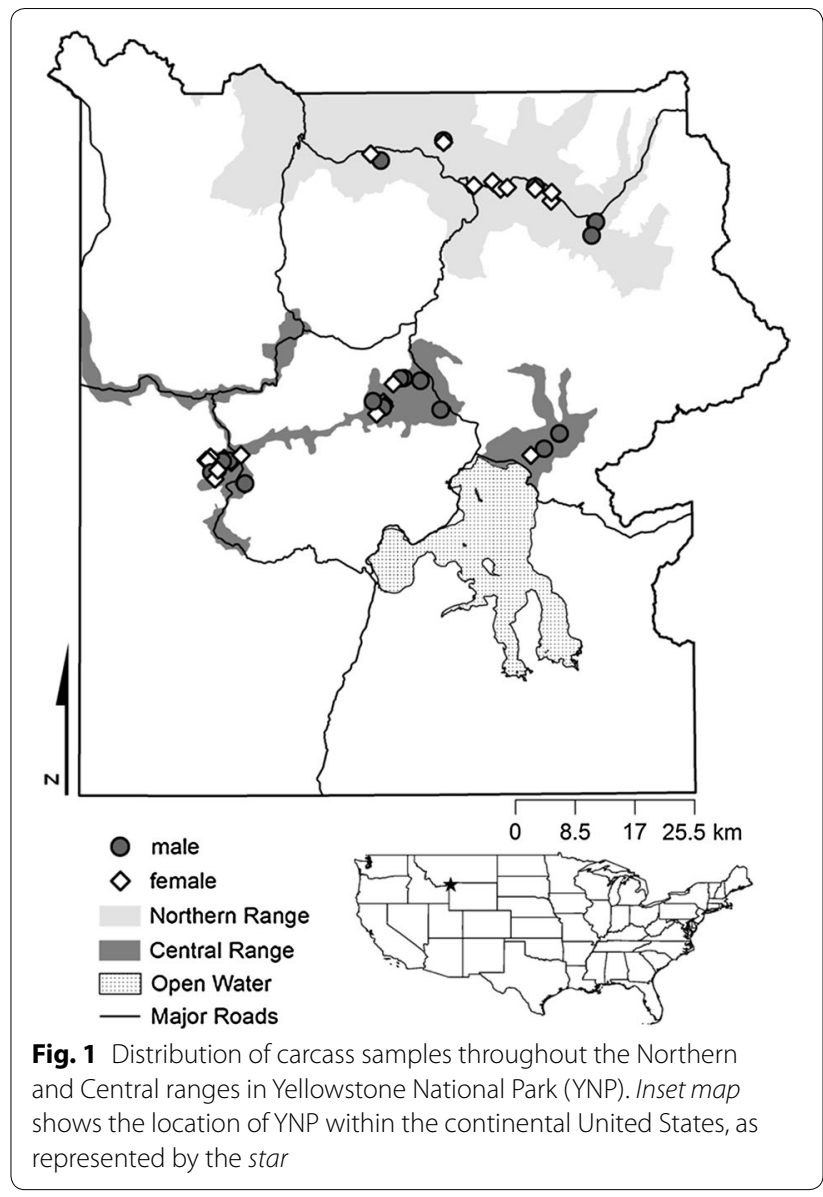

altitude and colder temperatures in the Central Range result in deeper snow cover, which remains significantly longer than in the Northern Range [22, 23]. The Central Range also has higher levels of geothermal activity than the Northern Range, resulting in greater abundance of winter forage [24]. However, the quality of forage located on geothermal patches tends to be of relatively low quality, with elevated levels of fluoride and silica [25]. The two ranges also differ in bedrock geology and soil type [23]. The Northern Range is dominated by andesitic bedrock, which generates soils that are richer in plant-available nutrients and organic carbon compared to soils generated by rhyolitic bedrock, which is prevalent across the Central Range [23]. Population growth of bison in YNP is thought to be contingent on herbivore density and winter-forage availability [26]. In general, Yellowstone National Park is considered to be forage-limited [26], and population densities of both elk and bison are greater on the Northern Range compared to those of the Central Range [27, 28]. Spatial and temporal variations in the biotic and abiotic environments should be reflected in the quality, abundance, and distribution of forage available to 
bison throughout YNP and therefore, also reflected in the composition and quality of their diets.

If different sexes face different nutritional demands, then differences in forage quality and density-dependent influences on forage availability and selection should be reflected in how similar (or different) the diets of males and females are within each range. Moreover, the degree of diet segregation between males and females within each range should vary between the mating and nonmating seasons. In the Central Range, bison and elk densities are relatively low throughout the year $[27,28]$. As a result, animals in this region of the park likely experience strong density-dependent effects during late summer, when animals form large, mixed-sex mating groups. Thus, diet segregation in the Central Range should be most pronounced during this time, and should be in sharp contrast to the degree of diet segregation we might observe throughout the rest of the year. In the Northern Range, bison and elk densities are considerably higher, and as a result, animals in this region of the park likely experience strong density-dependent effects throughout the entire year. While ungulate densities in the Northern Range may also peak during the mating season, differences in the degree of diet segregation between the mating and non-mating seasons are likely less pronounced than that which we might observe on the Central Range.

Using fecal nitrogen and stable isotopes of carbon $\left(\delta^{13} \mathrm{C}\right)$ and nitrogen $\left(\delta^{15} \mathrm{~N}\right)$, we evaluated whether male and female bison in YNP exhibit diet segregation and whether the degree of diet segregation varies within each range during mating season and across a time period spanning multiple years. To determine whether diet segregation of bison in YNP is associated with sex-specific nutritional demands and whether these demands are met differently in each range, we tested four hypotheses. (1) Male and female bison have distinct diet compositions during the mating season and (2) across multiple years. (3) Male and female bison from the Central Range differ more in diet composition (i.e., show more pronounced diet segregation) during the mating season than across multiple years. (4) Male and female bison from the Northern Range have different diet compositions, regardless of season. Regardless of time period or range, we expect females to have higher quality diets than males. Finally, during the mating season, males are most concerned with tending potential mates in an effort to maximize breeding potential, and thus, the variety of forages available to both males and females should be similar during this time. As a result, we expect males and females to have similar dietary breadths during the mating season, but statistically distinct dietary breadths throughout the multi-year period, regardless of range.

\section{Methods}

\section{Study area}

Yellowstone National Park occupies 891,000 ha of primarily forested habitat in northwestern Wyoming, USA, and ranges from 1500 to $3300 \mathrm{~m}$ in elevation [27]. During the summer months, the park is home to an estimated 3700 bison [29] that reside principally in two areas, the Central Range and the Northern Range (Fig. 1). As winter approaches, bison move to lower elevations, including the lower Yellowstone River drainage and Blacktail Deer Plateau in the Northern Range, where snow pack is shallower and the growth of spring vegetation begins earlier [30]. As noted above, distinct biotic and abiotic differences between the two ranges influence the abundance and distribution of high-quality forage for bison in YNP [23].

\section{Analytical methods}

Fecal nitrogen is an established measure of dietary quality [31], and stable isotopes, especially of carbon and nitrogen, are commonly used to investigate dietary differences both within and among mammal populations [32]. The primary source of nitrogen in feces of mammalian herbivores is dietary protein, although plant secondary metabolites that bind to proteins as well as microbial sources of nitrogen may influence estimates of protein in feces [31]. Regardless, absolute forage intake [33], forage digestibility, and dietary protein are positively correlated with fecal $\mathrm{N}$ in grazing ungulates [34]. Stable isotopes of carbon found in the biogenic materials of herbivores (e.g., feces and collagen) reflect the average $\delta^{13} \mathrm{C}$ of plants ingested and assimilated during the formation of these materials $[35,36]$. Thus, $\delta^{13} \mathrm{C}$ is commonly used to distinguish diet compositions of large herbivores using mathematical mixing models [37]. Even without the use of mixing models, however, both the mean and variance of stable isotopes provide information about dietary habits. Differences in mean $\delta^{13} \mathrm{C}$ have been used to analyze population differences in diet [38], and individual variation in $\delta^{13} \mathrm{C}$ from biogenic materials (e.g., feces and bone) provides a measure of dietary breadth within a population. As animals ingest a greater range of plant species and plant parts, the variance of $\delta^{13} \mathrm{C}$ increases $[39,40]$. In general, the mean $\delta^{15} \mathrm{~N}$ of animal tissues reflects the protein content of the animal's diet [41, 42], with a negative correlation between the nitrogen content of ingested plants and $\delta^{15} \mathrm{~N}$ values of herbivore bone collagen $\left(\delta^{15} \mathrm{~N}_{\text {collagen }}\right.$; [43]).

Stable isotopes of carbon and nitrogen from bone collagen and feces, along with fecal $\mathrm{N}$ content, provide information about diet over different temporal windows. Bone formation is a relatively continuous process [44], and bone collagen has a turnover rate on the order of years 
$[45,46]$. Thus, the isotopic composition of bone collagen reflects the average foraging trends over much of the lifetime of sampled individuals (i.e., multi-year). Stable isotope values from bison fecal samples, in contrast, reflect the isotopic composition of forage ingested during the previous $24-48 \mathrm{~h}$ [47].

\section{Sample collection}

We collected 60 fecal samples from bison in the Northern and Central ranges (15 males and 15 females from each range) over a period of 10 days during the mating season of early August 2009. We monitored animals along the periphery of the herd and when defecation occurred, we recorded a compass bearing in the direction of that potential sample, as well as any landmarks useful in determining the precise location of that sample (e.g., tree, bushes, flowers, mounds, etc.). No two samples were collected within close spatial proximity of one another (i.e., approximately $20 \mathrm{~m}$ ) within the same herd, and samples were collected within $2 \mathrm{~h}$ of elimination. All fecal samples came from animals of reproductive age ( $\geq 6$ years for males and $\geq 2$ years for females); one fecal sample from the Central Range had to be discarded due to molding. We determined whether animals were of reproductive age based on size, head morphology, and pelage (mature males have well-defined manes that are absent on females and immature males; [48]).

The YNP scientific staff provided the locations of bison carcasses from adult animals that had died over the previous 36 months. Sample collection took place between 15 July and 7 August 2009. We collected 22 hemi-mandibles and 18 vertebrae from 40 carcasses. Twenty-five of the sampled carcasses were from the Central Range (13 females, 12 males), and 15 (11 females, 4 males) were from the Northern Range (Fig. 1). We estimated age at time of death using patterns of cheek-tooth eruption and wear [49] and the degree of fusion of suture lines on the frontal bones of the skull [50]. We determined the sex of carcasses based on sex-specific morphological differences in the skull [51] and pelvic girdle [52, 53]. For stable isotope analysis of bone collagen, we collected hemimandibles; when a hemi-mandible could not be located, we collected a single vertebra.

\section{Sample preparation and analysis}

We dried fecal samples at $60^{\circ} \mathrm{C}$ until stable weights were achieved, then homogenized them in a SPEX Certiprep $8000 \mathrm{D}$ ball mill. We weighed $0.3 \pm 0.05 \mathrm{mg}$ of each sample and wrapped it in a Costech $5 \times 9 \mathrm{~mm}$ tin capsule for analysis of $\% \mathrm{~N}$ and $\delta^{13} \mathrm{C}$. For stable isotope analysis of bone collagen, we demineralized approximately $50 \mathrm{mg}$ of bone in $0.5 \mathrm{~N} \mathrm{HCl}$ for $72 \mathrm{~h}$ at $4{ }^{\circ} \mathrm{C}$. We then rinsed samples with de-ionized water and placed them in $6 \mathrm{ml}$ of chloroform/methanol lipid-extraction solution [54]. Finally, we lyophilized the samples for $24 \mathrm{~h}$ and then wrapped $0.3 \pm 0.05 \mathrm{mg}$ of collagen sample in a Costech $5 \times 9 \mathrm{~mm}$ tin capsule for analysis of $\delta^{13} \mathrm{C}$ and $\delta^{15} \mathrm{~N}$ [55].

Samples were analyzed in the Nadelhoffer Stable Isotope Laboratory at the University of Michigan Biological Station (Pellston, Michigan). Fecal and collagen samples were analyzed on a Thermo Delta Plus XL isotope ratio mass spectrometer via combustion in a Costech $\mathrm{CHN}$ analyzer, Model 4010. Analytical precision was estimated via multiple analyses of a caffeine standard (mean $\delta^{13} \mathrm{C}=-49.35, \mathrm{SD}=0.16$; mean $\delta^{15} \mathrm{~N}=-1.7 \%$, $\mathrm{SD}=0.12$ ). Stable isotope values of $\mathrm{C}$ and $\mathrm{N}$ were reported to the nearest 0.01 and $0.1 \%$, respectively, and fecal- $\mathrm{N}$ content $\left(\% \mathrm{~N}_{\text {feces }}\right)$ was reported to the nearest $0.01 \%$. Data acquisition and instrument control were accomplished using ISODAT 2.0. Isotopic values of feces and bone collagen were reported relative to international standards, Vienna Pee Dee Belemnite (VPDB) for carbon and atmospheric $\mathrm{N}$ for nitrogen.

\section{Statistical analysis}

We used multivariate analysis of variance (MANOVA) to determine whether diets differ throughout YNP as a function of sex and range. Specifically, we evaluated six different models (Table 1) to determine whether diets vary as a function of sex and range during the mating season (hypothesis 1 , model 1 ) and over a multi-year period (hypothesis 2, model 2) and whether diets of males and females differ during the mating season and over a multiyear period in both the Central (hypothesis 3, models 3.1 and 3.2, respectively) and Northern ranges (hypotheses 4, models 4.1 and 4.2 , respectively). For any tests resulting in $P<0.10$, we applied a univariate ANOVA to determine whether any of the dependent variables were significantly influenced by our independent variables (i.e., sex and range).

We also investigated differences in dietary breadth using Bartlett's test for homogeneity of variance [56]. We compared variance of $\delta^{13} \mathrm{C}_{\text {feces }}$ to determine if dietary breadth varied as a function of sex and range during the mating season and compared variance of $\delta^{13} \mathrm{C}_{\text {collagen }}$ to determine whether dietary breadth varied as a function of sex across a multi-year time period. While our sample sizes may seem small when subdivided by sex and range, Clementz and Koch [57] reported that a sample size of $n=5$ resulted in a standard error of $0.01 \%$ for the mean $\delta^{13} \mathrm{C}$ value of the study population and recommended $\geq 5$ as suitable sample size for stable isotope studies of populations. However, one of our collagen test groups, Northern Range males, had a sample size just below this threshold. To determine the influence of this small sample size, we calculated $95 \%$ confidence intervals for each sex-range 
Table 1 Structure and sample size for MANOVA models

\begin{tabular}{|c|c|c|c|c|c|c|}
\hline \multirow[t]{2}{*}{$\mathrm{H}_{\mathrm{a}}$} & \multirow[t]{2}{*}{$x$} & \multirow[t]{2}{*}{$y$} & \multirow[t]{2}{*}{ Time period } & \multicolumn{2}{|c|}{ Sample size } & \multirow[t]{2}{*}{ Model ID } \\
\hline & & & & Female & Male & \\
\hline 1 & Sex & $\delta^{13} C_{\text {feces }} \% \mathrm{~N}_{\text {feces }}$ & Mating season & 30 & 29 & 1 \\
\hline 2 & Sex & $\delta^{13} \mathrm{C}_{\text {collagen, }} \delta^{15} \mathrm{~N}_{\text {collagen }}$ & Multi-year & 24 & 16 & 2 \\
\hline \multirow[t]{2}{*}{3} & Sex, CR & $\delta^{13} C_{\text {feces }} \% \mathrm{~N}_{\text {feces }}$ & Mating season & 15 & 14 & 3.1 \\
\hline & & $\delta^{13} \mathrm{C}_{\text {collagen, }} \delta^{15} \mathrm{~N}_{\text {collagen }}$ & Multi-year & 13 & 12 & 3.2 \\
\hline \multirow[t]{2}{*}{4} & Sex, NR & $\delta^{13} C_{\text {feces }} \% \mathrm{~N}_{\text {feces }}$ & Mating season & 15 & 15 & 4.1 \\
\hline & & $\delta^{13} \mathrm{C}_{\text {collagen, }} \delta^{15} \mathrm{~N}_{\text {collagen }}$ & Multi-year & 11 & 4 & 4.2 \\
\hline
\end{tabular}

Models tested whether diet varies as a function of sex and range between mating season and a multi-year time period. To test hypotheses 3 and 4 , we subset the data for each range (CR, Central Range; NR, Northern Range), and analyzed the effect of sex on proxy measures for diet within each range. Columns labeled " $x$ " and " $y$ " denote the independent and dependent variables, respectively, for each model

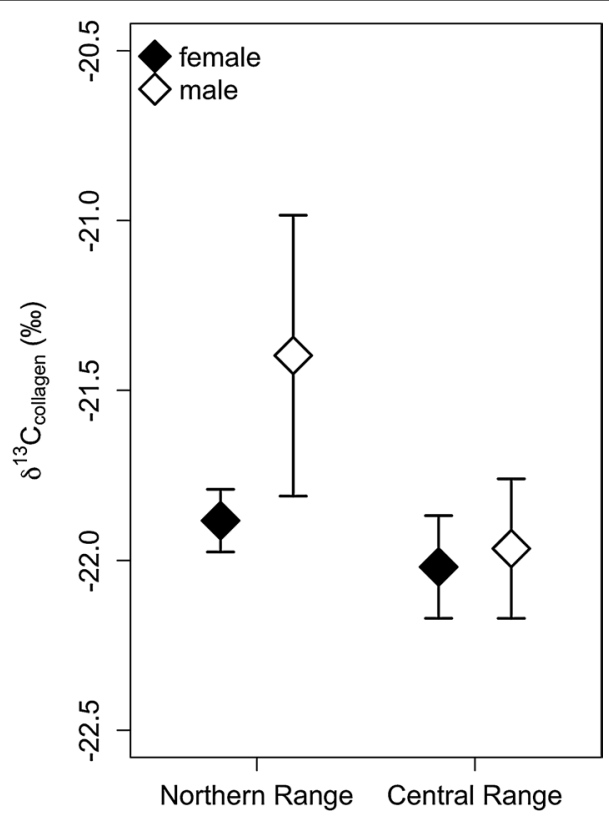

Fig. 2 Mean and 95\% confidence intervals for each combination of sex and range for $\delta^{13} \mathrm{C}$ of collagen $\left(\delta^{13} \mathrm{C}_{\text {collagen }}\right)$. Points represent mean values for $\delta^{13} C_{\text {collagen }}$ and bars represent $95 \%$ confidence intervals. Sample sizes for Northern Range bison are $\mathrm{n}=11$ for females and $\mathrm{n}=4$ for males, and sample sizes for Central Range bison are $\mathrm{n}=13$ for females and $n=12$ for males

combination (Fig. 2). Additionally, we performed an F test to compare the variance of Northern Range males $(n=4)$ to Central Range males $(\mathrm{n}=12)$ and found the variance between the two groups to be statistically indistinguishable $(\mathrm{F}=1.3463, \mathrm{P}=0.6193)$. All statistical analyses were performed using base packages in R 3.1.2 [58].

\section{Results}

Male and female bison throughout YNP had distinctly different diets during the mating season (Fig. 3; Table 2). While there was no difference in dietary breadth during this time (variance of $\delta^{13} C_{\text {feces }}$, Table 2), mean values of

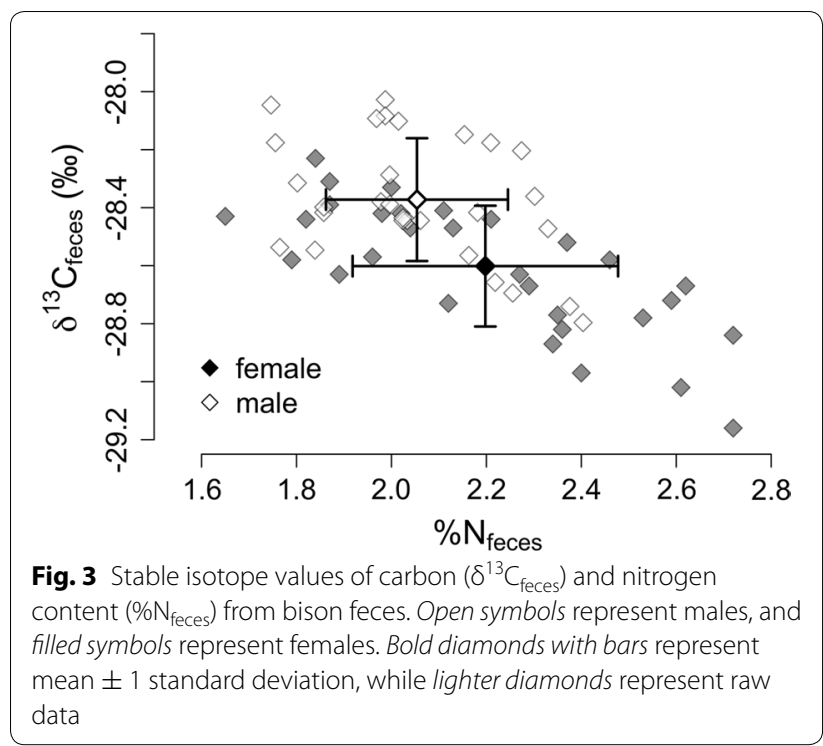

Table 2 Results for single-factor MANOVA tests and Bartlett's tests for homogeneity of variance

\begin{tabular}{|c|c|c|c|c|c|}
\hline \multirow[t]{2}{*}{ Model ID } & \multicolumn{2}{|c|}{ MANOVA } & \multirow[t]{2}{*}{$P$} & \multirow[t]{2}{*}{$K^{2}$} & \multirow{2}{*}{$\begin{array}{l}\text { Bartlett's test } \\
P\end{array}$} \\
\hline & df & $F$ & & & \\
\hline 1 & 1,57 & 8.698 & $<0.001^{*}$ & 0.008 & 0.931 \\
\hline 2 & 1,38 & 2.991 & 0.063 & 7.175 & $0.007^{*}$ \\
\hline 3.1 & 1,27 & 11.915 & $<0.001^{*}$ & 1.718 & 0.190 \\
\hline 3.2 & 1,23 & 1.434 & 0.260 & 0.781 & 0.377 \\
\hline 4.1 & 1,28 & 2.025 & 0.153 & 1.430 & 0.232 \\
\hline 4.2 & 1,13 & 5.403 & $0.021^{*}$ & 5.076 & $0.024^{*}$ \\
\hline
\end{tabular}

Statistically significant results $(P<0.05)$ for both tests are identified with an asterisk. Bartlett's test for homogeneity of variance was used to analyze differences in variance of $\delta^{13} C_{\text {feces }}$ (mating season) and $\delta^{13} C_{\text {collagen }}$ (multi-year)

$\delta^{13} C_{\text {feces }}$ were significantly different between sexes indicating distinct diet compositions. Females had greater fecal nitrogen $\left(\% \mathrm{~N}_{\text {feces }}\right)$ than males (Fig. 3; Table 3), 
Table 3 Univariate ANOVA results for MANOVA tests with $P<0.10$

\begin{tabular}{|c|c|c|c|c|c|c|c|c|}
\hline \multirow[t]{2}{*}{ Model ID } & \multirow[t]{2}{*}{$x$} & \multirow[t]{2}{*}{$y$} & \multicolumn{2}{|c|}{ Mean values } & \multirow[t]{2}{*}{$d f$} & \multirow[t]{2}{*}{ SS } & \multirow[t]{2}{*}{$F$} & \multirow[t]{2}{*}{$P$} \\
\hline & & & Female & Male & & & & \\
\hline \multirow[t]{2}{*}{1} & \multirow[t]{2}{*}{ Sex } & $\delta^{13} C_{\text {feces }}$ & -28.61 & -28.36 & 1,57 & 0.904 & 17.570 & $<0.001^{*}$ \\
\hline & & $\% \mathrm{~N}_{\text {feces }}$ & 2.20 & 2.04 & 1,57 & 0.357 & 5.292 & $0.025^{*}$ \\
\hline \multirow[t]{2}{*}{2} & \multirow[t]{2}{*}{ Sex } & $\delta^{13} C_{\text {collagen }}$ & -21.96 & -21.82 & 1,38 & 0.171 & 1.536 & 0.223 \\
\hline & & $\delta^{15} N_{\text {collagen }}$ & 3.94 & 4.46 & 1,38 & 2.583 & 4.905 & $0.033^{*}$ \\
\hline \multirow[t]{2}{*}{3.1} & \multirow[t]{2}{*}{ Sex, CR } & $\delta^{13} C_{\text {feces }}$ & -28.76 & -28.38 & 1,27 & 1.056 & 18.670 & $<0.001^{*}$ \\
\hline & & $\% \mathrm{~N}_{\text {feces }}$ & 2.46 & 2.14 & 1,27 & 0.713 & 20.410 & $<0.001^{*}$ \\
\hline \multirow[t]{2}{*}{4.2} & \multirow[t]{2}{*}{ Sex, NR } & $\delta^{13} C_{\text {collagen }}$ & -21.88 & -21.40 & 1,13 & 0.691 & 11.550 & $0.005^{*}$ \\
\hline & & $\delta^{15} \mathrm{~N}_{\text {collagen }}$ & 3.66 & 3.82 & 1,13 & 0.076 & 0.228 & 0.641 \\
\hline
\end{tabular}

Significant difference in $\delta^{13} \mathrm{C}$ values between males and females indicates different dietary sources during each respective time period. Higher \% $\mathrm{N}_{\text {feces }}$ indicates higher quality diets during the mating season, whereas lower $\delta^{15} \mathrm{~N}_{\text {collagen }}$ indicates higher quality diet during the multi-year time period. Stable isotope values are reported to the nearest $0.01 \%$, and $\% \mathrm{~N}_{\text {feces }}$ is reported to the nearest $0.01 \%$. Columns labeled " $x$ " and " $y$ " denote the independent and dependent variables, respectively, for each model

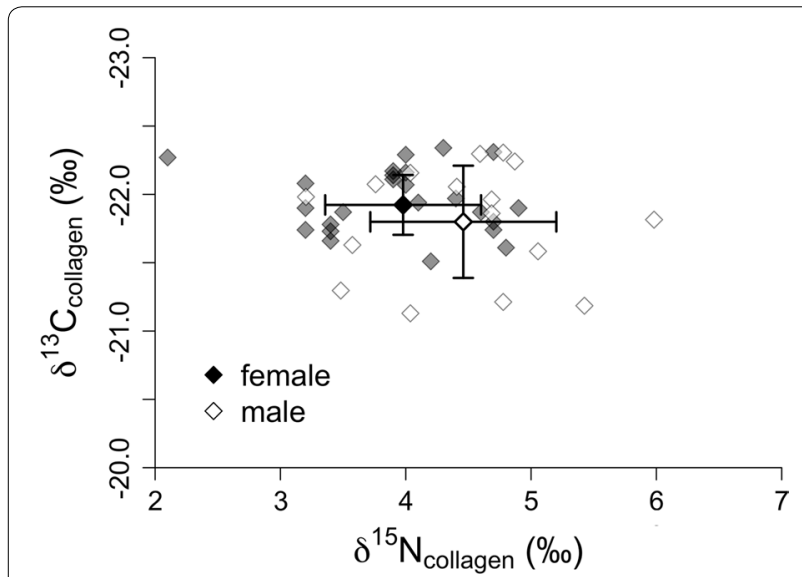

Fig. 4 Stable isotope values of carbon $\left(\delta^{13} \mathrm{C}_{\text {collagen }}\right)$ and nitrogen $\left(\delta^{15} \mathrm{~N}_{\text {collagen }}\right)$ from collagen tissue of male and female bison. Open symbols represent males, and filled symbols represent females. Bold diamonds with bars represent mean \pm 1 standard deviation, while lighter diamonds represent raw data

indicating higher quality diets during the mating season. Throughout the multi-year period, there was no difference in mean $\delta^{13} \mathrm{C}_{\text {collagen }}$ (Fig. 4; Table 3) between sexes, indicating that males and females ingest similar plants or plant parts, on average. Despite having similar mean diet compositions, as a group, males had greater dietary

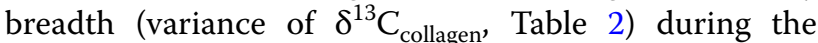
multi-year period, whereas females had higher quality diets, as indicated by lower $\delta^{15} \mathrm{~N}_{\text {collagen }}$ (Fig. 4; Table 3).

In the Central Range, male and female bison had significantly different diets during the mating season but not across the multi-year period (Table 2). Mean values of $\delta^{13} C_{\text {feces }}$ differed significantly between sexes in the Central Range, indicating distinct diet compositions during the mating season. Females had greater $\% \mathrm{~N}_{\text {feces }}$ compared to males (Table 3), indicating higher quality diets; however, there was no difference in dietary breadth between sexes during this time (variance $\delta^{13} C_{\text {feces}}$, Table 2). During the multi-year period, male and female diets in the Central Range were statistically indistinguishable in all regards, indicating diets of similar composition $\left(\delta^{13} \mathrm{C}_{\text {collagen }}\right)$, quality $\left(\delta^{15} \mathrm{~N}_{\text {collagen }}\right)$, and breadth (variance $\delta^{13} C_{\text {collagen }}$, Table 2$)$.

In contrast to what we observed in the Central Range, male and female bison in the Northern Range had significantly different diets during the multi-year period but not during the mating season (Table 2). During mating season, male and female diets in the Northern Range were statistically indistinguishable in all regards, indicating diets of similar composition, quality, and breadth (Table 2). However, during the multi-year period, $\delta^{13} C_{\text {collagen }}$ differed significantly between sexes, indicating sex-specific differences in mean diet composition (Table 3). Finally, although males had greater dietary breadth (variance $\delta^{13} \mathrm{C}_{\text {collagen, }}$, Table 2) during the multiyear period in the Northern Range, there was no difference in diet quality $\left(\delta^{15} \mathrm{~N}_{\text {collagen }}\right.$, Table 3$)$.

\section{Discussion}

We studied whether diet segregation of bison in YNP is associated with sex-specific nutritional demands and whether these demands are met differently in each range. We tested four hypotheses and found complete or partial support for each. Specifically, we found that mean diet composition of male and female bison during the mating season differs significantly, with females having higher quality diets and males having greater dietary breadth (hypothesis 1). Further, while mean diet composition for male and female bison throughout multiple years is statistically indistinguishable, females have higher quality 
diets and males have greater dietary breadth (hypothesis 2). Additionally, diet segregation for bison in the Central Range was more pronounced during the mating season than across the multi-year period; while females had higher quality diets than males during this time, there was no difference in dietary breadth (hypothesis 3 ). Finally, diet segregation in the Northern Range was more pronounced across the multi-year period than during the mating season; while males had greater dietary breadth during this time, there was no difference in diet quality (hypothesis 4 ).

Our results suggest that diet segregation of bison in YNP is associated with sex-specific nutritional demands and density-dependent influences associated with meeting these demands. During mating season, the diets of male and female bison are composed of different plants or plant parts (based on differences in $\delta^{13} C_{\text {feces }}$ ), with females consuming higher quality diets on average (higher $\% \mathrm{~N}_{\text {feces }}$ ). Although the difference in $\delta^{13} \mathrm{C}_{\text {feces }}$ between sexes is small $(0.25 \%)$, it represents more than $20 \%$ of the total range of $\delta^{13} \mathrm{C}_{\text {feces }}$ values. Over the multi-year time period, male and female bison, on average, consume a similar array of plants or plant parts throughout the park (based on similarity of $\delta^{13} \mathrm{C}_{\text {collagen }}$ ). Despite the similarity in average diet composition, however, females have higher quality diets (lower $\delta^{15} \mathrm{~N}_{\text {collagen }}$ ) than males and appear to be more consistent in their use of available forages (lower variance in $\left.\delta^{13} \mathrm{C}_{\text {collagen }}\right)$. Collectively, these results suggest that females exhibit more selective feeding behavior throughout the majority of the year compared to males. Numerous field studies of ungulates have reported that, while different sexes may forage in the same habitats, their diets can differ significantly, with females usually selecting forage of higher quality $[7,59,60]$. For example, dietary overlap of male and female white-tailed deer decreases during periods of aggregation (e.g., mating season) compared to periods of segregation [61], and fecal nitrogen of females is greater than that of males, regardless of season [62].

Despite the fact that the two bison populations studied are separated by only tens of kilometers, we found evidence of opposing responses of sex-specific diet segregation in the two ranges. In the Central Range, diet segregation in bison was apparent during the mating season but not during the multi-year period, whereas in the Northern Range, diet segregation was apparent during the multi-year period but not during the mating season. In the Central Range, although males and females obtained a majority of their forage from different plants or plant parts during the mating season, with females ingesting higher quality forage, there was no difference in dietary breadth. Over the multi-year period, males and females from the Northern Range obtained a majority of their forage from different plants or different plant parts. While there was no sex-specific difference in dietary quality for Northern Range bison during this time, males consumed a greater diversity of dietary items compared to females. Opposing responses of diet segregation in each range may result from differences in the abundance and distribution of high-quality forage and the varying degree of competition for this forage across different ranges and different time periods.

While the Yellowstone ecosystem is considered to be forage-limited for its ungulate herbivores, competition for forage is likely greater on the Northern Range than on the Central Range [26]. The Northern Range offers high-quality forage throughout much of the year, and population densities of elk and bison are greater on the Northern Range, especially during the mating season [27, 28]. Although competition for forage peaks during the mating season for bison in both the Northern and Central ranges, range-specific differences in the availability of high-quality forage may help explain the differences in diet segregation.

Another important consideration is the abundance and distribution of potential predators. While predation rates on bison vary throughout the park, elk are the primary prey of wolves in Yellowstone. In the Northern Range, where elk are most abundant, bison make up only about $4 \%$ of wolf kills, with elk comprising approximately $80 \%$ of kills [21]. Elk are much less abundant in the Central Range, and as a result, wolf predation rates on bison are higher there than anywhere else in the park, with approximately $10 \%$ of wolf kills in this region consisting of bison and around $40 \%$ of kills consisting of elk [20]. Moreover, while bison populations without predators have been characterized by the forage selection hypothesis $[5,16]$, populations with predators have been characterized by the predation risk hypothesis [60], in which females select habitats that offer increased safety at the cost of decreased food quality [63, 64]. Evidence suggests that the presence of potential predators can result in decreased foraging activity $[65,66]$, thereby directly influencing diet quality of prey [67]. Altogether, our results suggest that bison in Yellowstone National Park are best characterized by the forage selection hypothesis.

Although we interpret our results in the context of the forage selection hypothesis, our results are also consistent with the niche trade-off framework described by Bowyer [8], in which overlap on one niche axis (e.g., space) is accompanied by avoidance on another (e.g., diet). During mating season in YNP, females outnumber males by about 2-1 [68, 69]. Thus, males may be at a competitive disadvantage for those plants that females prefer but that make up at least a portion of male diets during the rest of the year. However, intraspecific competition as a driver of diet segregation in ruminants has been rejected several times in the literature [70,71], and testing this 
hypothesis is beyond the scope of this study. Although higher densities of females during the mating season may exclude males from consuming certain forages, these differences are best explained by morphological differences between sexes resulting in different physiologies and therefore different nutritional demands. Specifically, it has been hypothesized that a significant increase in the ingestion of high-quality forage by males could lead to mal-absorption, bloat, and ultimately, decreased digestive efficiency [72]. For comparison, in southern Texas, adult white-tailed deer shifted to lower quality diets as levels of intraspecific competition increased, with dietary shifts of males being more pronounced than those of females [61]. However, the authors rejected competition as a cause for sexual segregation and suggested that predator avoidance by females with young best explained the observed pattern [61]. Similarly, bighorn sheep in Sierra Nevada, California exhibited stronger niche differentiation during periods of spatial overlap than during periods of spatial separation [73]; however, the authors noted that these differences are most likely explained either by morphological differences or by how different sexes manage risk of predation [73]. It is also important to note that male ruminants tend to restrict feeding behavior during mating season [74], potentially resulting in decreased dietary breadth and lower variance of $\delta^{13} \mathrm{C}$ during periods of aggregation.

Finally, many studies investigating isotopic variation among conspecifics on different dietary regimes or in different regions have found only minor differences in isotope values between test groups. For example, several populations of mule deer with significant differences in fecal $\mathrm{N}$ content exhibited only small differences in mean $\delta^{15} \mathrm{~N}_{\text {feces}}$, ranging from -0.54 to $1.10 \%$ [75]. Similarly, a study investigating the isotopic composition of hair in cattle (Bos taurus) from different confinement and dietary practices found that six of 13 test groups had mean $\delta^{13} \mathrm{C}$ values within a range of less than 1\% [76]. Cattle, elk, and mule deer in Starkey Experimental Forest, Oregon, had a collective $\delta^{13} \mathrm{C}$ range of less than $2 \%$ and a collective $\delta^{15} \mathrm{~N}$ range of less than 4\% [39]. In YNP, Feranec reported that mean $\delta^{13} \mathrm{C}$ values of feces collected over a 1 -month period from bison, elk, mule deer, and whitetailed deer (O. virginianus) fell within a range of less than $1 \%$, and mean $\delta^{13} \mathrm{C}$ values of collagen for bison, elk, and mule deer lay within a range of about 2\%o [77]. Moreover, of the large herbivores resident to YNP, bison had the smallest $\delta^{13} \mathrm{C}$ range for feces and collagen, both of which were $0.9 \%$. Thus, while differences in forage type, feeding strategy (e.g., browser vs. grazer), and ecological setting may result in only small differences in isotopic values, these differences may correspond to biologically significant variations in diet [78]. Finally, while some of our sample sizes may seem small for groups divided by sex and range, all but one sample size was well over the recommended threshold for stable-isotopic characterization of populations [53]. For the sample that lay below this threshold, Northern Range males, the variance is statistically indistinguishable from that of Central Range males, which has three times the number of samples. Regardless, this particular result should be considered preliminary. Also, the threshold value for sample size was determined for enamel carbonate samples, not for collagen and fecal isotopes; however, more recent studies corroborate these findings using collagen isotopes [79].

\section{Conclusions}

Ecological theory suggests that smaller-bodied, female bison should displace males from high-quality foraging habitats, since females forage in large groups and deplete resources more rapidly than do males [2, 3, 7]. Based on our results, female bison in YNP have higher quality diets than males do, suggesting that diet segregation is associated with sex-specific nutritional demands. Additionally, range-specific differences in the abundance and distribution of high-quality forage, in conjunction with seasonal variation in population density of bison and elk, may influence spatial and temporal differences in diet segregation. Altogether, our results highlight the importance of accounting for spatiotemporal heterogeneity when conducting dietary studies on wild ungulates.

\section{Authors' contributions \\ $J L B$ and CB formulated the study idea and developed the study methods. $J L B$ conducted fieldwork, laboratory work, and analyzed the data. JLB and CB wrote the manuscript. Both authors read and approved the final manuscript. \\ Author details \\ 1 Department of Fisheries, Wild life, and Conservation Biology, University of Minnesota, 135 B Skok Hall, 2003 Upper Buford Circle, St. Paul, MN \\ 55108-1052, USA. ${ }^{2}$ Department of Ecology and Evolutionary Biology, Univer- sity of Michigan, 1109 Geddes Avenue, Ann Arbor, MI 48109-1079, USA.}

\section{Acknowledgements}

We thank S. Gunther, C. Hendrix, C. Curry, and B. Guild for providing logistical support and R. Wallen and K. Gunther for familiarizing us with Yellowstone National Park and its wildlife populations. We thank A. Pfrimmer for help in collecting carcass and fecal samples and J. LeMoine and M. Grant for guidance during stable isotope analysis. The suggestions of P. Myers and K. Nadelhoffer significantly improved this study. R. Feranec, D. L. Fox, and anonymous reviewers provided constructive comments on the manuscript.

\section{Competing interests}

The authors declare that they have no competing interests.

\section{Availability of data and materials}

The datasets analyzed in the current study are available from the corresponding author on reasonable request.

\section{Ethics approval and consent to participate}

All samples were collected under National Park Service Scientific Research and Collecting Permit number YELL-2009-SCI-5812. The remaining bone samples have been reposited at the University of Michigan Museum of Zoology, Ann Arbor, Michigan. 


\section{Funding}

The University of Michigan provided financial support via the Rackham Graduate Student Research Grant, the Department of Ecology and Evolutionary Biology Block Grants, and the Frontiers Master's Fellowship Program in the Department of Ecology and Evolutionary Biology.

\section{Publisher's Note}

Springer Nature remains neutral with regard to jurisdictional claims in published maps and institutional affiliations.

\section{Received: 21 March 2017 Accepted: 5 July 2017}

Published online: 14 July 2017

\section{References}

1. Mysterud A. The relationship between ecological segregation and sexual body size dimorphism in large herbivores. Oecologia. 2000;124:40-54.

2. Bell RH. A grazing ecosystem in the Serengeti. Sci Am. 1971;225:86-93.

3. Jarman P. The social organisation of antelope in relation to their ecology. Behaviour. 1974:48:215-67.

4. Perez-Barberia FJ, Pérez-Fernández E, Robertson E, Alvarez-Enriquez B. Does the Jarman-Bell principle at intra-specific level explain sexual segregation in polygynous ungulates? Sex differences in forage digestibility in Soay sheep. Oecologia. 2008;157:21-30.

5. Post DM, Armbrust TS, Horne EA, Goheen JR. Sexual segregation results in differences in content and quality of bison (Bos bison) diets. J Mammal. 2001;82:407-13.

6. Ruckstuhl KE. Foraging behaviour and sexual segregation in bighorn sheep. Anim Behav. 1998;56:99-106.

7. Du Toit JT. Sex differences in the foraging ecology of large mammalian herbivores. In: Ruckstuhl K, Neuhaus P, editors. Sexual segregation in vertebrates: ecology of the two sexes. Cambridge: Cambridge University Press; 2006. p. 35-52.

8. Bowyer RT. Sexual segregation in ruminants: definitions, hypotheses, and implications for conservation and management. J Mammal. 2004:85:1039-52.

9. Main MB, Du Toit JT. Sex differences in reproductive strategies affect habitat choice in ungulates. In: Ruckstuhl K, Neuhaus P, editors. Sexual segregation in vertebrates: ecology of the two sexes. Cambridge: Cambridge University Press; 2006. p. 148-62.

10. Ruckstuhl KE, Neuhaus P. Sexual segregation in ungulates: a comparative test of three hypotheses. Biol Rev Camb Philos Soc. 2002;77:77-96.

11. Berger J, Peacock M. Variability in size-weight relationships of Bison bison. J Mammal. 1988;69:618-24.

12. Main MB, Weckerly FW, Bleich VC. Sexual segregation in ungulates: new directions for research. J Mammal. 1996;77:449-61.

13. Robbins C. Wildlife feeding and nutrition. Atlanta: Elsevier; 2012.

14. Forsyth DM, Duncan RP, Tustin KG, Gaillard J-M. A substantial energetic cost to male reproduction in a sexually dimorphic ungulate. Ecology. 2005;86:2154-63.

15. Larter NC. Diet and habitat selection of an erupting wood bison population. Master's thesis. University of British Columbia, Vancouver; 1988.

16. Mooring MS, Reisig DD, Osborne ER, Kanallakan AL, Hall BM, Schaad EW, et al. Sexual segregation in bison: a test of multiple hypotheses. Behaviour. 2005;142:897-927.

17. Gogan PJP, Podruzny KM, Olexa EM, Pac HI, Frey KL. Yellowstone bison fetal development and phenology of parturition. J Wildl Manag. 2005;69:1716-30

18. Christianson DA, Gogan PJP, Podruzny KM, Olexa EM. Incisor wear and age in Yellowstone bison. Wildl Soc Bull. 2005:33:669-76.

19. Gardipee FM. Development of fecal DNA sampling methods to assess genetic population structure of Greater Yellowstone bison. Master's thesis. The University of Montana, Missoula; 2007.

20. Becker MS, Garrott RA, White PJ, Gower CN, Bergman EJ, Jaffe R. Wolf prey selection in an elk-bison system: choice or circumstance? Terr Ecol. 2008:3:305-37.

21. Smith D, Stahler D, Albers E, Metz M, Williamson L, Ehlers N, et al. Yellowstone wolf project: annual report 2008 (YCR-2009-03). National Park Service, Yellowstone center for resources; 2009.
22. Despain DG. Two climates of Yellowstone National Park. Proc Mont Acad Sci. 1987:47:11-9.

23. Despain DG. Yellowstone vegetation: consequences of environment and history in a natural setting. Boulder: Roberts Rinehart Publishers; 1990.

24. Fournier RO. Geochemistry and dynamics of the Yellowstone National Park hydrothermal system. Annu Rev Earth Planet Sci. 1989;17:13-53.

25. Garrott RA, Eberhardt LL, Otton JK, White PJ, Chaffee MA. A geochemical trophic cascade in Yellowstone's geothermal environments. Ecosystems. 2002;5:659-66.

26. Gates CC, Stelfox B, Muhly T, Chowns T, Hudson RJ. The ecology of bison movements and distribution in and beyond Yellowstone National Park: a critical review with implications for winter use and transboundary population management. The United States National Park Service; 2005.

27. Smith DW, Mech LD, Meagher M, Clark WE, Jaffe R, Phillips MK, et al. Wolf-bison interactions in Yellowstone National Park. J Mammal. 2000:81:1128-35.

28. Smith DW, Drummer TD, Murphy KM, Guernsey DS, Evans SB. Winter prey selection and estimation of wolf kill rates in Yellowstone National Park, 1995-2000. J Wildl Manag. 2004;68:153-66.

29. McDonald T, Carlson E, Patterson A, Zaluski M, Jones A, McDonald K, et al. 2012 Annual report of the interagency bison management plant. 2012.

30. White PJ, Wallen RL, Hallac DE, Jerrett JA, editors. Yellowstone bisonconserving an american icon in modern society. Yellowstone National Park: Yellowstone Association; 2015.

31. Leslie DM, Bowyer RT, Jenks JA. Facts from feces: nitrogen still measures up as a nutritional index for mammalian herbivores. J Wildl Manag. 2008;72:1420-33.

32. Cerling T, Harris J, Leakey M. Browsing and grazing in elephants: the isotope record of modern and fossil proboscideans. Oecologia. 1999;120:364-74.

33. Stallcup OT, Davis GV, Shields L. Influence of dry matter and nitrogen intakes on fecal nitrogen losses in cattle. J Dairy Sci. 1975;58:1301-7.

34. Lancaster RJ. Estimation of digestibility of grazed pasture from faeces nitrogen. Nature. 1949;163:330-1.

35. Cerling T, Harris J. Carbon isotope fractionation between diet and bioapatite in ungulate mammals and implications for ecological and paleoecological studies. Oecologia. 1999;120:347-63.

36. Deniro M, Epstein S. Influence of diet on the distribution of carbon isotopes in animals. Geochim Cosmochim Acta. 1978;42:495-506.

37. Phillips DL. Converting isotope values to diet composition: the use of mixing models. J Mammal. 2012;93:342-52.

38. Angerbjörn $A$, Hersteinsson $P$, Lidén $K$, Nelson E. Dietary variation in arctic foxes (Alopex lagopus) — an analysis of stable carbon isotopes. Oecologia. 1994:99:226-32.

39. Stewart KM, Bowyer RT, Kie JG, Dick BL, Ben-David M. Niche partitioning among mule deer, elk, and cattle: do stable isotopes reflect dietary niche? Ecoscience. 2003;10:297-302

40. Newsome SD, Tinker MT, Monson DH, Oftedal OT, Ralls K, Staedler MM, et al. Using stable isotopes to investigate individual diet specialization in California sea otters (Enhydra lutris nereis). Ecology. 2009;90:961-74.

41. Ambrose SH. Effects of diet, climate and physiology on nitrogen isotope abundances in terrestrial foodwebs. J Archaeol Sci. 1991;18:293-317.

42. Schoeninger MJ, DeNiro MJ. Nitrogen and carbon isotopic composition of bone collagen from marine and terrestrial animals. Geochim Cosmochim Acta. 1984:48:625-39.

43. Sealy JC, van der Merwe NJ, Thorp JAL, Lanham JL. Nitrogen isotopic ecology in southern Africa: implications for environmental and dietary tracing. Geochim Cosmochim Acta. 1987;51:2707-17.

44. Glimcher MJ. Bone: nature of the calcium phosphate crystals and cellular, structural, and physical chemical mechanisms in their formation. Rev Mineral Geochem. 2006;64:223-82.

45. Koch PL. Isotopic study of the biology of modern and fossil vertebrates. In: Michener R, Lajtha K, editors. Stable isotopes in ecology and environmental science. 2nd ed. Malden: Blackwell Publishing Ltd; 2008. p. 99-154.

46. Rubenstein D, Hobson K. From birds to butterflies: animal movement patterns and stable isotopes. Trends Ecol Evol. 2004;19:256-63.

47. Rutley BD, Hudson RJ. Seasonal energetic parameters of free-grazing bison (Bison bison). Can J Anim Sci. 2000;80:663-71.

48. Reynolds HW, Gates CC, Glaholt RD. Bison. Wild mammals of North America: biology, management, and conservation. 2nd ed. Baltimore: The Johns Hopkins University Press; 2003. p. 1009-60. 
49. Frison GC, Reher CA. Age determination of buffalo by teeth eruption and wear. Plain Anthropol. 1970;15:46-50.

50. Skinner MF, Kaisen OC. The fossil bison of Alaska and preliminary revision of the genus. Bull Am Mus Nat Hist. 1947;89:1-154.

51. Shackleton DM, Hills LV, Hutton DA. Aspects of variation in cranial characters of plains bison (Bison bison bison Linnaeus) from Elk Island National Park, Alberta. J Mammal. 1975;56:871-87.

52. Edwards JK, Marchinton RL, Smith GF. Pelvic girdle criteria for sex determination of white-tailed deer. J Wildl Manag. 1982;46:544-7.

53. Tyler NJC. Sexual dimorphism in the pelvic bones of Svalbard reindeer, Rangifer tarandus platyrhynchus. J Zool. 1987:213:147-52.

54. Bligh EG, Dyer WJ. A rapid method of total lipid extraction and purification. Can J Biochem Physiol. 1959;37:911-7.

55. Burton RK, Koch PL. Isotopic tracking of foraging and long-distance migration in northeastern Pacific pinnipeds. Oecologia. 1999;119:578-85.

56. Sokal RR, Rohlf FJ. Bartlett's test of homogeneity of variances. Biometry. San Francisco: WH Freeman and Co.; 1969. p. 370-89.

57. Clementz MT, Koch PL. Differentiating aquatic mammal habitat and foraging ecology with stable isotopes in tooth enamel. Oecologia. 2001;129:461-72.

58. R Core Team. R: A language and environment for statistical computing. R Foundation for Statistical Computing; 2013. http://www.R-project.org. Accessed 7 Mar 2014

59. Clutton-Brock TH, Guinness FE, Albon SD. Red deer: behavior and ecology of two sexes. Chicago: University of Chicago Press; 1982.

60. Komers PE, Messier F, Gates CC. Group structure in wood bison: nutritional and reproductive determinants. Can J Zool. 1993;71:1367-71.

61. Kie JG, Bowyer RT. Sexual segregation in white-tailed deer: densitydependent changes in use of space, habitat selection, and dietary niche. J Mammal. 1999;80:1004-20.

62. Gallina S, Sánchez-Rojas G, Buenrostro-Silva A, López-González CA. Comparison of faecal nitrogen concentration between sexes of whitetailed deer in a tropical dry forest in southern Mexico. Ethol Ecol Evol. 2015;27:103-15.

63. Festa-Bianchet M. Seasonal range selection in bighorn sheep: conflicts between forage quality, forage quantity, and predator avoidance. Oecologia. 1988;75:580-6.

64. Conradt L. Definitions, hypotheses, models and measures in the study of animal segregation. In: Ruckstuhl K, Neuhaus PJP, editors. Sexual segregation in vertebrates: ecology of the two sexes. Cambridge: Cambridge University Press; 2006. p. 11-32.

65. Lima SL, Dill LM. Behavioral decisions made under the risk of predation: a review and prospectus. Can J Zool. 1990;68:619-40.
66. Altendorf KB, Laundré JW, López González CA, Brown JS. Assessing effects of predation risk on foraging behavior of mule deer. J Mammal. 2001;82:430-9

67. Hernández L, Laundré JW. Foraging in the "landscape of fear" and its implications for habitat use and diet quality of elk Cervus elaphus and bison Bison bison. Wildl Biol. 2005;11:215-20.

68. Wolff JO. Breeding strategies, mate choice, and reproductive success in American bison. Oikos. 1998;83:529-44.

69. Bowyer RT, Bleich VC, Manteca X, Whiting JC, Stewart KM. Sociality, mate choice, and timing of mating in American bison (Bison bison): effects of large males. Ethology. 2007;113:1048-60

70. Conradt L, Gordon IJ, Clutton-Brock TH, Thomson D, Guinness FE. Could the indirect competition hypothesis explain inter-sexual site segregation in red deer (Cervus elaphus L.)? J Zool. 2001;254:185-93.

71. Conradt L, Clutton-Brock TH, Thomson D. Habitat segregation in ungulates: are males forced into suboptimal foraging habitats through indirect competition by females? Oecologia. 1999;119:367-77.

72. Barboza PS, Bowyer RT. Sexual segregation in dimorphic deer: a new gastrocentric hypothesis. J Mammal. 2000;81:473-89.

73. Schroeder CA, Bowyer RT, Bleich VC, Stephenson TR. Sexual segregation in Sierra Nevada bighorn sheep, Ovis canadensis sierrae: ramifications for conservation. Arct Antarct Alp Res. 2010:42:476-89.

74. Miquelle DG. Why don't bull moose eat during the rut? Behav Ecol Sociobiol. 1990;27:145-51.

75. Darimont CT, Paquet $P C$, Reimchen TE. Stable isotopic niche predicts fitness of prey in a wolf-deer system. Biol J Linn Soc. 2007:90:125-37.

76. Schwertl M, Auerswald K, Schäufele R, Schnyder H. Carbon and nitrogen stable isotope composition of cattle hair: ecological fingerprints of production systems? Agric Eco Environ. 2005;109:153-65.

77. Feranec RS. Stable carbon isotope values reveal evidence of resource partitioning among ungulates from modern C3-dominated ecosystems in North America. Palaeogeogr Palaeoclimatol Palaeoecol. 2007;252:575-85.

78. Singer FJ, Norland JE. Niche relationships within a guild of ungulate species in Yellowstone National Park, Wyoming, following release from artificial controls. Can J Zool. 1994;72:1383-94.

79. Fox-Dobbs K, Bump JK, Peterson RO, Fox DL, Koch PL. Carnivore-specific stable isotope variables and variation in the foraging ecology of modern and ancient wolf populations: case studies from Isle Royale, Minnesota, and La Brea. Can J Zool. 2007:85:458-71.

\section{Submit your next manuscript to BioMed Central and we will help you at every step:}

- We accept pre-submission inquiries

- Our selector tool helps you to find the most relevant journal

- We provide round the clock customer support

- Convenient online submission

- Thorough peer review

- Inclusion in PubMed and all major indexing services

- Maximum visibility for your research

Submit your manuscript at www.biomedcentral.com/submit
BioMed Central 